\title{
MARX E OS OUTROS
}

Jean Tible para Mauro William Barbosa de Almeida

Era Marx eurocêntrico? Propõe-se aqui, para responder a esta pergunta, uma leitura dos seus escritos que abordam formações sociais e econômicas, lutas e acontecimentos que vão além da Europa Ocidental.

\section{Entre os estágios de desenvolvimento e a crítica do colonialismo}

Um primeiro aspecto dos escritos de Marx aqui estudados é sua busca em desvendar os estágios de desenvolvimento e da evolução social e sua correlata apreensão de situações concretas. Em A ideologia alemã, Marx e Engels esboçam uma sucessão histórica dos modos de produção. Para os autores, "os vários estágios de desenvolvimento da divisão do trabalho são, apenas, outras tantas formas diversas de propriedade”.

O primeiro estágio é o da propriedade tribal, no qual a estrutura social corresponde à estrutura da família e a subsistência é garantida pela caça e pesca, pela criação de animais e, às vezes, pela agricultura. Não há desenvolvimento da produção e a divisão de trabalho é elementar. A segunda forma situa-se na Antiguidade e sua propriedade é comunal e estatal. 
Tendo a cidade como origem, ocorre a separação do trabalho industrial e agrícola e a distinção entre cidade e campo.

Sua sequência - a terceira etapa histórica da propriedade - é a feudal. A propriedade transforma-se em "propriedade coletiva dos senhores feudais, como um grupo, apoiados pela organização militar dos conquistadores tribais germânicos é sua base" (Marx e Engels, 2007 [1845-1846],pp. 89-91). Seu ponto de partida é o campo e a classe explorada não é mais composta por escravos, mas por servos. A quarta formação, o capitalismo, é produto da evolução do feudalismo. Funda-se na distinção entre cidade e campo, quando ocorre um desenvolvimento das manufaturas e aguçam-se a competição e guerras comerciais entre as nações. Trata-se de uma nova fase do desenvolvimento histórico, em que predominam as relações e conflitos entre capitalistas e trabalhadores.

Tal perspectiva dos estágios se mantém no Manifesto comunista. São, no entanto, citadas somente as três formas 200 de sociedade de classe, sem levar em conta a anterior, sem classes - a tribal -, o que será acrescentado por Engels em prefácios posteriores. "A história de todas as sociedades até agora tem sido a história das lutas de classe", colocam Marx e Engels (2001 [1848], p. 8), citando a sociedade escravista da Antiguidade, o feudalismo e a sociedade burguesa.

Os autores enfatizam o escopo planetário do capitalismo e os elos entre a ascensão da burguesia e o colonialismo. Com o novo mundo que se abre com a "descoberta da América e a circunavegação da África”, a exploração desses mercados e seu comércio "trouxeram uma prosperidade até então desconhecida". A colonização prepara a criação desse mercado mundial e este se impõe às demais formas sociais, num ímpeto de unificação. A ação burguesa "logra integrar na civilização até os povos mais bárbaros”, graças aos revolucionários progressos na produção e comunicação. Em tons épicos, os autores narram de que forma "os preços baratos de suas mercadorias são a artilharia pesada com a qual ela derruba todas as muralhas da 
China". A burguesia, dessa forma, "cria um mundo à sua imagem e semelhança” (Marx e Engels, 2001 [1848], pp. 9-12).

Alguns anos mais tarde, Marx (2011 [1857-1858]) retoma esta discussão em "As formas sociais que precedem o capitalismo" - as Formen -, momento privilegiado de sua reflexão acerca do pré-capitalismo. Marx investiga os mecanismos das transformações sociais e evolução histórica, compreendidos de acordo com o desenvolvimento das forças produtivas materiais. $\mathrm{O}$ autor apreende, assim, quatro vias alternativas de desenvolvimento a partir do sistema comunal primitivo e sua propriedade comum da terra - oriental, antiga, germânica e eslava (cf. Marx, 2011 [1857-1858]). A novidade situa-se no sistema ora caracterizado como "oriental" ora como "asiático" e, antes disso, esboçado como "despotismo oriental” em cartas trocadas com Engels (cf. Bert, 2010) e em artigos publicados no New York Daily Tribune no mesmo ano de 1853. Sua base ainda é a propriedade comunal e Marx liga-a - sem, no entanto, desenvolver o raciocínio - às sociedades pré-colombianas mexicana e peruana.

Na "Introdução geral” de 1857 e no "Prefácio" de 1859, Marx (2011 [1857-1858]) aborda os estágios de desenvolvimento das formas de produção. Por um lado, pensa nos modos asiático, antigo, feudal e burguês moderno como "épocas progressivas da formação econômica da sociedade. As relações de produção burguesas são a última forma antagônica do processo social de produção”. Suas forças produtivas criam as condições materiais para superar tal antagonismo e "com esse sistema social é a pré-história da sociedade humana que se encerra" (pp. 487-88). Por outro lado, Marx (pp. 451-53; grifo no original) adverte que "é possível confundir ou apagar todas as diferenças históricas formulando leis humanas universais" e insiste na importância do aspecto empírico - "as condições ditas gerais não são outra coisa que esses momentos abstratos que não permitem apreender tal estágio histórico real da produção". 
Os estágios mencionados indicam o estado dos estudos de Marx nesse momento, constituindo mais indicações iniciais do que uma compreensão acabada. Tal apreensão dos estágios de desenvolvimento liga-se à sua análise de situações concretas. Em Londres - centro do maior império -, desde 1849, Marx amplia seu escopo de interesse e começa a pensar situações além da Europa Ocidental e aqui já é possível perceber uma tensão entre os horrores do colonialismo e a necessária marcha civilizatória, sendo seu exemplo mais paradigmático talvez os artigos sobre a Índia.

Marx escreve, em "The British rule in India" (Avineri, 1969, p. 93), que a colonização britânica destrói a tecelagem indiana e também as "pequenas comunidades semibárbaras e semicivilizadas, acabando com seus fundamentos econômicos e produzindo, assim, a maior e por assim dizer a única revolução social jamais vista na Ásia”. Ora, continua Marx, se a dissolução dessa vida dos vilarejos significa tristeza do 202 ponto de vista dos sentimentos humanos, seus moradores atinham-se a um universo demasiado estreito, tornando-os instrumentos dóceis de superstição e escravos das regras, sem esquecer a existência das castas e da escravidão em seu seio.

Em artigo posterior no mesmo ano, "The future of British rule in India” (Avineri, 1969), os horrores do colonialismo tampouco são olvidados, a Inglaterra sendo "guiada pelos interesses mais abjetos" e mostrando sem véu na Índia a "barbárie inerente à civilização burguesa". Marx argumenta, porém, que a sociedade indiana não possui história, a não ser que se considerem as invasões sucessivas por cima da "base passiva dessa sociedade imutável e sem resistência". Assim, a escolha não se situa acerca de uma invasão ou não da Inglaterra, mas entre uma desta e a de outro país, tal como a Turquia, Rússia ou Pérsia.

Tampouco deixa de estar presente o caráter, em última instância, positivo da expansão capitalista, já que a Inglaterra "tem uma dupla missão a exercer na Índia: uma destrutiva, 
outra regeneradora”. Em sua visão, uma futura revolução redimirá esses processos, pois tais terríveis convulsões resultarão numa forma superior de organização social. Retoma Marx, com ecos do Manifesto, que o período burguês da história cria um novo mundo, via intercâmbio universal e desenvolvimento das forças produtivas. E efetua um paralelo entre as transformações do comércio e a indústria burgueses com as revoluções geológicas, defendendo que no momento em que uma "grande revolução social conseguir dominar os resultados dos tempos burgueses" e "sujeitá-lo ao controle comum dos povos mais avançados, aí então o progresso humano deixará de parecer àquele horrível figura, ídolo pagão que só bebia néctar nos crânios de suas vítimas"1. E semelhante abordagem está presente nos artigos sobre a China da mesma época ${ }^{2}$.

Ocorre, desse modo, um tento de encaixar tais realidades em estágios preestabelecidos e numa teleologia linear e "otimista" da história. Fascinado pela expansão capitalista, Marx emite, com Engels, julgamentos expeditivos a respeito da índole de diferentes povos: mexicanos preguiçosos, beduínos ladrões, indianos estagnados, frente aos enérgicos ianques, civilizados franceses e progressistas ingleses. A agência e o protagonismo são apreendidos como situados do lado europeu ocidental e estadunidense. Pensando nesses estágios do desenvolvimento e em alguns exemplos correlatos, cabe perguntar: existem sociedades imutáveis pré-capitalistas e mutáveis capitalistas? Qual o lugar da Europa ocidental na história e no mundo? Seria o capitalismo inevitável e progressista e as forças pré-capitalistas obstáculos reacionários?

O que significa essa predominância da sociedade burguesa (e europeia ocidental) em relação às demais? Trata-se, para Marx, da forma mais complexa de todas, situada num outro patamar de desenvolvimento e estando no centro

\footnotetext{
${ }^{1}$ Ver "The future of British rule in India" [8 ago. 1853], em Avineri (1969, p. 139).

2 Ver "The revolution in China and in Europe" [14 jun. 1853], em Avineri (1969, p. 67).
} 
da história. Seu interesse pelas formações pré-capitalistas se deve ao fato de as capitalistas serem produtos históricos dessas formações. De acordo com Marx (2011 [1857-1858], p. 169), "a sociedade burguesa é a organização histórica da produção mais desenvolvida e mais diferenciada”, e, assim, "a anatomia do homem é uma chave para a anatomia do macaco". Manifesta-se, assim, um tipo de confiança na história, por conta da sucessão de estágios. Para além de suas violências, o capitalismo é prenhe de comunismo; o modo de produção capitalista cria as formas materiais - e desperta as forças - de sua destruição.

A compreensão marxiana dos estágios evolutivos não pode ser apreendida, entretanto, sem sua concomitante denúncia dos massacres provocados por esse curso da história. Há uma sempre presente crítica ao colonialismo que muda de forma e se reforça e uma mudança no que toca às suas análises de algumas situações concretas (China, Esta204 dos Unidos, Índia, Irlanda). Para Marx, o esquema linear perde força, inclusive pelo autor se debruçar nos aspectos empíricos, por virar "sociólogo" ou "antropólogo".

Já nos artigos sobre a Índia, publicados em 1853, Marx, colocava que "a profunda hipocrisia e a barbárie inerente da civilização burguesa mostra-se sem véus aos nossos olhos, passando de seu lar natal, onde ela assume formas respeitáveis, para as colônias onde se apresenta sem véus"3. Essa tensão, presente nos dez artigos do mesmo ano sobre a Índia, se reforça nos 31 de 1857, sobre a insurreição indiana, suas causas e derrota final. No primeiro período (1853), Marx faz uma análise inicial sobre o colonialismo, mas possui ainda poucas informações sobre a Ásia e se guia mais por abstrações filosóficas. Nesse contexto, os colonizados não fazem sua própria história e Edward Said (2007 [1978]) critica Marx por esses motivos.

${ }^{3}$ Ver "The future of British rule in India", em Avineri (1969, p. 137). 
Estaria certo Said ao assimilar Marx ao orientalismo? Nos artigos de 1857 em particular, tal argumento perde força e, não por acaso, Said atém-se aos de 1853. Nesse segundo momento, Marx se "afastou de um foco exclusivo na burguesia britânica para pensar as atividades e lutas dos indianos colonizados" (Jani, 2002, p. 82), denunciando a tortura dos ingleses como uma "uma instituição orgânica" da política colonial e de sua retórica racista.

É sobretudo a partir dos anos 1860 que Marx adotará outra postura. A colonização estadunidense do México havia sido analisada como progresso histórico. Isso, no entanto, muda "no caso da defesa do México contra a política anexionista dos Estados Unidos" (cf. Marx, 1972) e, no momento em que se prepara um ataque, Marx defende que "a planejada intervenção no México por parte da Inglaterra, França e Espanha, é, na minha opinião, um dos mais monstruosos empreendimentos já cronicados nos anais da história internacional" . Acrescenta, ainda, que "o Blue Book da intervenção no México [...] contém a maior exposição para condenar a diplomacia inglesa moderna com todo seu hipócrita jargão de ferocidade contra os fracos, seu rastejar frente aos ricos e sua total desconsideração do direito internacional" 6 .

Isso se reflete, também, na questão irlandesa. Em carta a Engels em 10 de dezembro de 1869, Marx marca explicitamente sua mudança ao dizer que inicialmente pensava possível a derrubada do regime irlandês pela ascensão da classe trabalhadora inglesa, o que expressou em artigos no jornal New York Daily Tribune. Porém, estudos aprofundados levam Marx à convicção de que a classe operária inglesa nada alcançará sem antes resolver a questão irlandesa. Essa é a alavanca e, por isso, um ponto chave para o movimento

\footnotetext{
${ }^{4}$ Ver "The Indian revolt" [16 set. 1857], em Avineri (1969, p. 224).

${ }^{5}$ Ver "The intervention in Mexico" [23 nov. 1861], em Avineri (1969, p. 425).

${ }^{6}$ Ver "The Mexican imbroglio" [10 mar. 1862], em Avineri (1969, p. 433).
} 
social em geral ${ }^{7}$. Marx reinterpreta os laços entre Inglaterra e Irlanda em termos coloniais. Uma das principais fontes de riqueza da aristocracia fundiária inglesa advém dessa dominação, que provoca a migração dos trabalhadores pobres irlandeses para as cidades industriais inglesas que, por sua vez, pressiona para baixo os salários operários. $\mathrm{O}$ que causa, também, a xenofobia, já que o operário inglês, como membro de uma nação dominante é, de certo modo, instrumentalizado pelos capitalistas do seu país, que utilizam esse sentimento contra os irlandeses.

Marx prega um necessário rompimento da classe operária com a política das classes dominantes, os trabalhadores ingleses devendo fazer causa comum com irlandeses - parte importante dos trabalhadores na Inglaterra -, pois este "antagonismo constitui o segredo da impotência da classe operária inglesa" 8 ainda impede uma aliança entre operários na Inglaterra e nos Estados Unidos, 206 defende Marx numa resolução do Conselho Geral da Internacional. A Irlanda representa, igualmente, o único motivo para manutenção de um grande exército na Inglaterra, e este pode se voltar, quando precisar, contra os operários ingleses.

Reforça-se, assim, o anticolonialismo de Marx. Ademais, tais situações concretas o levam a reinterpretar os elos entre colonialismo e capitalismo, na forma de relações de poder essenciais ao capitalismo mundial, inclusive no suprimento das matérias-primas obtido pelo "livre" mercado. Tal contexto passa a ser apreendido não tanto como força de modernização e mais como parte da hegemonia burguesa, com a descoberta dos novos mercados coloniais tendo evitado o agravamento da crise econômica de 1857.

\footnotetext{
${ }^{7}$ Ver Karl Marx, Carta para Engels, 10 dez. 1869. Disponível em: <http://marxists. org/archive/marx/works/1869/letters/69_12_10.htm>. Acesso em: 22 jul. 2012. ${ }^{8}$ Ver Karl Marx, Carta para Beesly, 16 set. 1870. Disponível em: <http://marxists. org/archive/marx/works/1870/letters/70_09_16.htm>. Acesso em: 22 jul. 2012.
} 
Em O capital, "Marx não retoma a história das 'formas que precedem a produção capitalista'. No lugar dela, no final do mesmo primeiro volume, logo após tratar da lei geral da acumulação capitalista, aparece a análise brilhante da 'acumulação originária do capital'” (Almeida, 2003, p. 48). Nos capítulos finais, "A chamada acumulação originária" e "A teoria moderna da colonização", Marx pensa as relações entre a Inglaterra - e a Europa ocidental - e o resto do mundo. Caminha, assim, no sentido da existência de um sistema capitalista colonial.

No penúltimo capítulo do primeiro volume de $O$ capital, Marx recapitula sua argumentação, citando a transformação do dinheiro em capital e depois do capital em mais-valia e desta em mais capital. Entretanto, nos diz o autor, forma-se um círculo vicioso: tal acumulação de capital pressupõe uma mais-valia e esta o capital e força de trabalho. Falta algo, alguma explicação e Adam Smith fala nesse contexto de uma "acumulação prévia”, uma acumulação antes da acumulação capitalista. Esta é, segundo Marx, o equivalente na economia política do pecado original na teologia.

Ao contrário da narrativa da economia clássica que fala de uma concentração precedente, ocorre uma "violenta produção das condições da possibilidade da relação capitalista de produção" (Mezzadra, 2008, p. 133). O eixo de compreensão se desloca: da necessidade histórica para a conquista. Indo contra a visão idílica da acumulação inicial, Marx afirma o processo histórico de separação do produtor rural dos meios de produção. A história dessa expropriação "está inscrita nos anais da humanidade em letra de sangue e fogo", o capital vindo ao mundo "transbordando de sangue e de sujeira por todos os poros, da cabeça aos pés".

Sua forma clássica ocorre na Inglaterra, no fim do século XV, com a pilhagem dos bens da Igreja e decretos - as bills for Inclosure of Commons - de cercamento das terras comunais, que permitiram a expropriação. Isso criou "para 
a indústria das cidades o aporte necessário de proletariado explorável à vontade", pois os camponeses foram expulsos de suas terras. Assim, "o povo do campo, brutalmente expropriado e expulso de sua terra, reduzido à vagabundagem, foi restrito por leis de um terrorismo grotesco à disciplina necessária ao salariado por chicotadas, marcas de ferro vermelho e torturas".

Tais atrozes violências ligam-se à exploração da América, África, Ásia e de suas populações. Descreve Marx (2006 [1867], p. 843):

[...] a descoberta de terras de ouro e prata na América, o extermínio, escravização e enterramento da população nativa nas minas, o início da conquista e pilhagem das Índias Orientais, a transformação da África numa coutada para a caça comercial dos peles-negras, assinalam a aurora da era da produção capitalista. Estes processos idílicos são momentos principais da acumulação original. Lhes seguem de perto a guerra comercial das nações europeias, com o globo terrestre por palco. Inicia-se com a revolta dos Países Baixos contra a Espanha, toma contornos gigantescos na Inglaterra com a guerra antijacobina e prolonga-se ainda na guerra do ópio contra a China.

Esse sistema colonial possui papel fundamental, sendo o “'deus estrangeiro' que veio a se colocar no altar ao lado dos velhos ídolos da Europa" (Marx, 2006 [1867], pp. 80552). É, também, no dito Novo Mundo que Marx desvenda o segredo do modo de produção e acumulação capitalista. Sua base consiste na expropriação do trabalhador, "aquilo a que os economistas chamam 'Acumulação Prévia ou Original', mas deve ser chamada Expropriação Original’ (Marx, 1987 [1865], p. 46).

Além de apontar os elos entre capitalismo e colonialismo, Marx também pensa seus vínculos com a escravidão. Se 
sempre a condenou, agora a integra à sua compreensão do capitalismo e das lutas pela emancipação da classe trabalhadora. Em carta ao escritor russo Pavel Vasilyevich Annenkov, em dezembro de 1846, e em A miséria da filosofia, no ano seguinte, Marx coloca lado a lado a indústria moderna e a escravidão; esta no Suriname, Brasil e sul dos Estados Unidos "é tão o pivô no qual nosso industrial do dia a dia gira quanto o são as máquinas, crédito, etc. Sem escravidão não haveria algodão, sem algodão, não haveria indústria moderna" .

Esse argumento é expandido nos escritos de Marx sobre a Guerra Civil Americana, pois os Estados escravistas "cresceram e se desenvolveram simultaneamente ao monopólio da indústria algodoeira inglesa no mercado mundial”. Ademais, não dissocia a emancipação dos negros da classe operária estadunidense, a primeira sendo uma condição para a segunda, como aparece na saudação da I Internacional a Abraham Lincoln, escrita por Marx (1946, pp. 325-27). Ligam-se exploração na Europa ocidental e no mundo em geral, pois "a escravidão camuflada dos operários assalariados na Europa necessitava do pedestal da escravidão sans phrase no novo mundo" (Marx, 2006, pp. 852-53).

Trata-se de uma virada no pensamento de Marx, segundo José Aricó (1982). Mas não "completa”, diz, por sua vez, o filósofo argentino Enrique Dussel (1990, p. 244), pois a "Irlanda só importava porque livraria o proletariado inglês; assim como a Polônia e a Turquia tinham sentido porque debilitariam a reacionária Rússia. Mas essas nações não valiam ainda por elas mesmas". Tais limites - reforçados - os acompanham em seus textos sobre a América Latina. Conforme coloca Aricó (1982, p. 82), "se, por um lado, [Marx] viu-se obrigado a reconhecer essa realidade 'nacional' na Irlanda, China, Índia, Espanha, Rússia ou mesmo na Tur-

\footnotetext{
${ }^{9}$ Ver Karl Marx, Carta para Pavel Vasilyevich Annenkov, dez. 1846. Disponível em: <http://www.marxists.org/archive/marx/works/1846/letters/46_12_28.htm>. Acesso em: 22 jul. 2012.
} 
quia, não parecia estar disposto a admiti-la em países como o México, Argentina ou Brasil". Isso "não porque a negara explicitamente na teoria, mas pela incapacidade de reconhecê-la nas lutas concretas destes povos". De acordo com o pensador argentino, a América Latina foi apreendida em sua exterioridade, limitando, assim, sua compreensão.

Marx, nos seus últimos anos, voltará a pensar na região, "mas agora com novas preocupações, como as formas de propriedade antigas, os efeitos da colonização, etc., dirigidas em grande parte precisamente a superar os vazios em sua compreensão da história e a sociedade latino-americana” (García Linera, 2008, pp. 50-51). Interessa-se, também, pela América do Norte em sua leitura de Lewis Morgan, que foi fundamental na transição do crescente anticolonialismo à incorporação da vitalidade dessas formas sociais outras.

\section{Marx transformado: vitalidade das outras formas sociais}

210 O interesse de Marx, após a publicação de $O$ capital centrou-se "nesta etapa do desenvolvimento social, para a qual Maurer, Morgan e a vasta literatura russa de que se ocupou, de 1875 em diante, proporcionaram uma base de estudos muito mais sólida do que a que estivera disponível em 1857-1858" (Hobsbawm, 1991 [1964], p. 49). Marx afeta-se por essas lutas outras. Isso pode ser percebido nos textos sobre a comuna rural russa e nas suas leituras de Morgan. São dois momentos chave: o debate com os russos acerca do destino da comuna rural explicita seu questionamento dos estágios de desenvolvimento e seu diálogo com Morgan o leva a pensar a riqueza da organização política iroquesa, ambos remetendo à incorporação de outros atores e movimentos.

O que interessou Marx na comuna rural e na situação russa? Quais as características específicas desta? O que a comuna rural russa os leva (Marx e Engels) a pensar? Num primeiro momento, a Rússia é vista como o bastião da reação na Europa e os autores estavam sobretudo interessados na diplomacia 
czarista e em suas conspirações contra qualquer intento revolucionário. A partir do fim dos anos 1860, Marx entra em contato com revolucionários e intelectuais russos e aí se inicia seu interesse pelos problemas políticos e sociais russos, em particular a questão agrária e uma possível revolução camponesa.

O sucesso da versão russa de $O$ capital foi decisivo para essa aproximação. O tradutor, o economista narodnik (populista) Nikolai Danielson, incentiva Marx a estudar as formas comunais de propriedade (cf. Rubel, 1974, p. 86). A partir desse momento, ele passa a ter contatos e trocas regulares com os jovens revolucionários, consolidando sua transformação. No início de 1870, Marx aprende russo para ter um contato direto com a literatura e debates locais e reúne uma documentação importante sobre o assunto. Numa carta a Engels, Jenny Marx conta sobre a nova tarefa de seu marido, relatando que ele começou a estudar russo como se fosse uma questão de vida ou morte, chegando a preencher 30 mil páginas de anotações sem, no entanto, finalizar nenhum texto ${ }^{10}$.

Um texto de Engels, "Os problemas sociais da Rússia”, marca o início desse processo de reflexão sobre a Rússia e suas potencialidades revolucionárias. Engels responde, a pedido de Marx, ao revolucionário Petr Tkatchev que o havia acusado, numa carta aberta, de ignorar a situação específica russa, assim como suas possibilidades emancipatórias. Para Tkatchev, a Rússia seria a terra prometida do socialismo, pois nem a burguesia nem o proletariado aí existiam e por haver fortes instituições comunitárias. Ele pensava, nesse contexto, a vitória do socialismo como uma questão política, na forma da derrubada do czarismo e da conquista do Estado pelos revolucionários.

Engels responde que o Estado russo trava qualquer revolução na Europa. Pensando na Alemanha, ele diz que

\footnotetext{
${ }^{10}$ Ver "Late Marx: gods and craftsmen”, em Shanin (1983, pp. 7-13).
} 
a revolução nesse país teria que imediatamente enfrentar o exército russo da reação, pensando assim na queda do Estado czarista como uma das condições para a vitória do proletariado alemão. Continua, colocando que a Rússia importa no sentido de não atrapalhar as possibilidades revolucionárias alemãs. Esse artigo marca uma transição em curso. Engels prossegue numa visão de que o camponês "vegeta miseravelmente de geração para geração num marasmo que está de algum modo fora da história" "11, mas abre a possibilidade de a comuna transformar-se num sentido socialista, se sair de seu atraso. Concorda, também, sobre a preparação em curso de uma revolução social na Rússia, mas ressalta a impossibilidade que esta assuma características socialistas, tendo em vista a ausência tanto de um proletariado numeroso como de uma burguesia capitalista forte. As formas comunitárias indicam uma aspiração dos russos a um modo de trabalho cooperativo e uma tendência a associar-se, mas

212 o parâmetro ainda é exterior; o mir pode unicamente transformar-se numa forma de organização superior se for precedido de uma revolução proletária na Europa ocidental, já que essas comunas rurais caminham para sua dissolução.

Dois anos mais tarde, em carta ao conselho editorial da revista russa Otechestvennye Zapiski (Notas da Pátria), Marx (1963, pp. 1553-55; grifos do autor) argumenta que, caso a Rússia prossiga no rumo seguido desde 1861, "perderá a mais bela oportunidade jamais ofertada a um povo, para padecer de todas as peripécias fatais do regime capitalista”. Questionado acerca de qual "aplicação" de $O$ capital na Rússia, contesta que se esta "tende a virar uma nação capitalista como as nações da Europa Ocidental, e durante estes anos está buscando esse caminho, ela não o conseguirá antes de haver transformado uma boa parte de seus camponeses em proletários".

\footnotetext{
${ }^{11}$ Ver Friedrich Engels, Carta para Bebel. 16-18 mar. 1875. Disponível em: <http:// www.marxists.org/archive/marx/works/1875/letters/75_03_18.htm>. Acesso em: 22 jul. 2012.
} 
Tendo feito isso, será levada à máquina capitalista e "viverá suas leis impiedosas, como outros povos profanos. É isto”.

O que não significa uma marcha obrigatória da história, pois não faz sentido, para Marx, transformar seu "esboço histórico da gênese do capitalismo na Europa ocidental numa teoria histórico-filosófica da marcha geral, fatalmente imposta a todos os povos, quais que sejam as circunstâncias históricas onde se encontram". Tal teoria histórico-filosófica geral, diz Marx, teria como principal virtude a de ser supra-histórica. Uma prova de que esse texto não é uma simples carta situa-se na mudança ou esclarecimento - nas edições posteriores de $O$ capital num trecho importante, a saber, a já citada expropriação dos camponeses (Wada, 1983, pp. 44-49). Marx reforça que o que havia escrito sobre a inevitabilidade histórica só era válido para os países da Europa ocidental - de onde saiu o capitalismo das entranhas do feudalismo e sua ordem econômica -, indicando novos olhares e propostas para problemas postos por movimentos oriundos de outros horizontes.

Logo, a Rússia e outros podem seguir caminhos distintos. Na troca de cartas com os russos, Marx utilizará essa nova edição francesa, como o faz na correspondência - e rascunhos - com Vera Zasulich. Esta era parte do movimento populista (narodnik), uma corrente revolucionária russa que questionava tanto o eslavismo dos que defendiam a especificidade - e superioridade - eslava como as ideias dos liberais e outros sobre capitalismo europeu como futuro obrigatório da Rússia. Defendia, assim, a possibilidade de um salto em direção a outra sociedade, sem passar pelo capitalismo. Seu autor mais conhecido foi Chernyshevskii e teve como expressão política o Narodnaya Volya (Partido da Vontade do Povo), organização clandestina que exerceria considerável influência no período entre 1879 e 1883 antes de ser esmagada com execuções e exílios ${ }^{12}$.

${ }^{12}$ Ver "Late Marx: gods and craftsmen”, em Shanin (1983, p. 8). 
Vera Zasulich pergunta a Marx, no contexto das discussões que $O$ capital gera na Rússia nos meios revolucionários, como questão de vida ou morte - pois dessa resposta dependeria o destino pessoal dos revolucionários russos: se a comuna rural, liberta dos pesados impostos e outros pagamentos aos senhores e à administração czarista, seria capaz de evoluir num rumo socialista, organizando-se em bases coletivistas? Nesse caso, o militante socialista deve centrar-se na libertação da comuna e no seu desenvolvimento. Ou, se os autointitulados marxistas estão corretos e essa comuna é uma forma arcaica cujo destino é perecer, de acordo com o socialismo científico, os militantes deveriam centrar-se em outras ações. Zasulich (1974, p. 1557) clama por uma exposição das ideias de Marx sobre o destino da comuna e sobre a "teoria da necessidade histórica para todos os países do mundo de passar por todas as etapas da produção capitalista”.

Marx leva três semanas para responder e redige quatro 214 rascunhos, antes de enviar sua versão definitiva. Qual sua resposta? Marx reafirma a condição mestra do sistema capitalista, a separação radical entre o produtor e seus meios de produção. E, citando $O$ capital, afirma sua realização de forma radical somente na Inglaterra, embora os demais países da Europa ocidental estejam na mesma onda. Nesse sentido, a "fatalidade histórica" restringe-se aos países nos quais uma forma de propriedade privada é substituída por outra forma de propriedade privada. Desse modo, responde Marx, a análise contida em $O$ capital não lhe permite dizer-se nem contra, nem a favor da comuna rural, mas "o estudo especial que fiz, e para o qual busquei material nas fontes originais, me convenceram que esta comuna é o ponto de apoio da regeneração social na Rússia”. Para isso, no entanto, "tem que ser eliminadas influências deletérias que a perseguem por todos os lados e, em seguida, lhe assegurar as condições normais de um desenvolvimento espontâneo" (Marx, 1974, p. 1558). 
Nos rascunhos da carta, Marx reforça alguns pontos importantes, como o de salientar que a ameaça à comuna não é uma "inevitabilidade histórica nem uma teoria; é a opressão estatal e a exploração por capitalistas intrusos que o Estado tornou poderosos em detrimento dos camponeses". Além disso, a contemporaneidade do mir com o modo capitalista de produção pode lhe permitir uma combinação única de circunstâncias, ou seja, "livrar-se de suas características primitivas e desenvolver-se diretamente como um elemento da produção coletiva em escala nacional". Poderia, assim, "apropriar-se de todos as realizações positivas sem passar por suas terríveis e temíveis vicissitudes" (Marx, 1983, p. 105). No entanto, isso envolve, também, livrar-se das características ditas primitivas do mir, onde "cada comunidade forma um todo fechado" e "se ligam entre si apenas por intermédio do 'paizinho, o czar' e apenas pelo poder supremo, patriarcal, que ele exerce" (Bakunin, 2003 [1873]).

Em suma, para responder à questão de Vera Zasulich, Marx propõe sair da teoria abstrata e ir à empiria russa. Situa, ademais, o fator decisivo: só uma revolução russa poderá salvar o mir. Assim, Marx, que nos anos 1860 era hostil aos narodniki, identificou posteriormente "por trás da ironia de Chernyshevskii e dos atentados a bomba da Vontade do Povo, uma densa análise e importantes insights de uma realidade que era diferente da sua, assim como algumas questões estratégicas e considerações que poderiam ocasionar novas perspectivas". Seus últimos escritos "mostram o quanto Marx adotou e desenvolveu novas visões a respeito da Rússia - enriquecendo sua própria análise e sendo crítico de si mesmo"13.

Os debates acerca do mir estão presentes no momento em que Marx e Engels redigem o prefácio à segunda edição

\footnotetext{
${ }^{13}$ Ver "Marxism and the vernacular revolutionary traditions", em Shanin (1983, p. 275).
} 
russa do Manifesto. Perguntam-se novamente se a comuna russa poderia passar diretamente para uma forma superior - isto é, comunista - de propriedade ou se deveria obrigatoriamente passar pelas etapas europeias ocidentais. Respondem os autores, que "se a revolução russa tornar-se o sinal para a revolução proletária no Ocidente, de modo que uma complemente a outra", então "a atual propriedade em comum da terra na Rússia poderá servir de ponto de partida para um desenvolvimento comunista" (Marx e Engels, 1996, pp. 43-44).

Ao mesmo tempo que debatiam os rumos do mir, Marx e Engels tinham contato com alguns trabalhos etnológicos. Marx liga a comuna russa aos ameríndios, ao citar Morgan em rascunho de carta para Vera Zasulich, ao colocar que "nas palavras de um escritor americano que... não é visto como tendo tendências revolucionárias, 'o novo sistema' em direção da qual a sociedade moderna tende 'será uma revives216 cência, numa forma superior, do tipo social arcaico" (Marx, 1983, p. 107). Esse contato com a etnologia transforma as ideias marxianas. Foi intenso o impacto da leitura de Ancient society, de Lewis Henry Morgan. Engels chega a dizer em carta a Karl Kautsky que "Morgan tornou possível vermos as coisas de pontos de vista inteiramente novos" (Rosemont, 1989, p. 210). Pontos de vista novos; pela primeira vez, o autor tem contato com relatos detalhados da existência concreta de uma sociedade sem classes, os iroqueses.

De acordo com o antropólogo estadunidense Lawrence Krader, tais leituras etnológicas ligam-se aos estudos a respeito das comunidades rurais - como as Formen - e aos debates sobre o mir russo. Morgan "proveu a base material para a doutrina da impermanência da propriedade em sua particular forma da propriedade privada [...]. Os manuscritos etnológicos complementam assim as posições dos Grundrisse e de $O$ capital'. Krader apresentou e organizou esses Cadernos etnológicos, publicados 89 anos após 
a morte de Marx e guardados no International Institute of Social History, em Amsterdã, Holanda. Nestes, Marx, entre 1880 e 1882, transcreve, anota e comenta trechos das obras de quatro antropólogos: Lewis Henry Morgan, John Budd Phear, Henry Summer Maine e John Lubbock. Além destes, Marx estudou, também, obras de Georg Maurer e Maxim Kovalevsky.

A intenção de Marx era apresentar esses trabalhos, embora não se saiba qual seria sua forma final, pois estava em gestação. Suas longas anotações são um quebra-cabeça. Marx, como de hábito, quando se interessava pelas obras, transcreveu fartamente o livro de Morgan. Anotou em detalhe a organização das partes e dos capítulos e, ainda, "na organização dos excertos e notas de Morgan, Marx permaneceu à parte, comparada com sua organização do material de Maine. [...] Suas concepções relativas a Morgan devem ser interpretadas ex silentio, pela sua escolha dos materiais". Marx destacou 130 trechos, com 25 comentários, que fornecem indicações preciosas sobre seus principais interesses no decorrer da leitura e releitura; 28 notas marginais tratam da organização política/governamental, da democracia primitiva, dos conselhos e o papel das mulheres, 27 trechos abordam a propriedade comunal, habitação e terra e outros 19 a posse comunal (cf. Krader, 1974).

Duas ideias de Morgan chamam particularmente a atenção de Marx. De um lado, a organização política dos iroqueses; de outro lado, o papel da propriedade na evolução histórica, esta sendo um divisor de águas. Seu interesse particular pelas formas políticas democráticas dos iroqueses é atestado pelo volume muito maior de trechos selecionados, representando a maior parte dos Cadernos etnológicos. Marx transcreveu de forma detalhada as cerimônias e ritos do Conselho iroquês. Tal Confederação unia as diferentes tribos iroquesas (Mohawks, Oneidas, Onondagas, Cayugas e Senecas) e baseava-se em uma série de direitos: eleger, depor os sachems e chefes 
e compromisso de ajuda e de defesa mútuas. Os princípios democráticos nasceram, para Morgan, nesse período, definindo esta como uma democracia de tipo arcaico. De acordo com Morgan (1964 [1877]), "princípios democráticos eram o elemento vital da sociedade gentílica, [...] uma destacada produção de sabedoria e sagacidade".

Morgan "era parte do movimento do pensamento americano, que estava ainda vivo, ligado à tradição de igualdade comum e às revoluções americana e francesa" (White, 1964 [1877], p. XXXVI), notadamente ao pensamento de Jefferson e sua democracia insurrecional (Raulin, 2010, p. 228). Antiaristocrata e defensor da difusão da propriedade, sua famosa conclusão, retomada por Marx, em rascunho para Vera Zasulich, e por Engels, no fim de A origem da família, da propriedade privada e do Estado, faz uma crítica da civilização contemporânea e prega uma incorporação de antigos elementos da humanidade numa forma vindoura (Morgan, 1964 [1877], p. 552).

218 Os estudos sobre o mir, os debates com revolucionários russos e a leitura de Morgan permitiram um deslocamento em Marx. Os relatos de Morgan sobre os iroqueses "deram a ele uma vívida atenção acerca da atualidade dos povos indigenas, e talvez mesmo um vislumbre da possibilidade de tais povos darem suas próprias contribuições à luta global pela emancipação humana" (Morgan, 1964 [1877]; grifos do autor). Nova ótica, nova abordagem. Marx manifesta, como vimos, uma hostilidade crescente ao colonialismo e ao capitalismo e passa a fazer uma apreciação distinta das forças potencialmente revolucionárias desses sujeitos outros, "pessoas de cor (people of color); nos colonizados, camponeses e 'primitivos'", o que faz seu genro Paul Lafargue escrever que ele voltou de Argel em 1882 "com sua cabeça cheia da África e dos árabes” (Rosemont, 1989, pp. 207-208).

Como explicar essa capacidade de Marx de se transformar? Por seu contato com as lutas. A riqueza do pensamento marxiano reside nisso, na sua "contaminação" pelas lutas. 
Quando questionado acerca do futuro do mir, Marx retrabalha o já escrito em $O$ capital, descendo da teoria pura para a realidade russa. Nesse sentido, "enquanto a primeira geração dos seus intérpretes lutavam infindavelmente pela pureza da dedução de seu mestre, Marx mesmo fez o oposto. Recusou-se a deduzir a realidade social dos seus próprios livros"14.

\section{Comunismo primitivo e por vir}

Após analisar os textos, cartas, rascunhos, transcrições e anotações de Marx acerca do mir russo e dos escritos antropológicos de sua época, em particular Morgan, pode-se dizer que ocorre uma mudança em que o autor passa a valorizar por si mesmas as experiências e formas de resistências que ocorrem fora dos países da Europa ocidental. Um ponto fundamental dessas formações sociais situa-se na propriedade comum da terra. Isso por dois aspectos. Por um lado, sua dissolução explica a origem da sociedade civil e do Estado, e, por outro, sua possível regeneração - em outras formas - é compreendida em termos comunistas. As mudanças de Marx no que toca às formações não ocidentais ligam-se ao estudo da propriedade fundiária.

Tal ponto-chave remete ao primeiro texto de Marx sobre uma questão material, no qual acompanha a discussão na Dieta renana para definir se a prática tradicional de colheita da lenha por parte dos pobres configurava-se num roubo ou não. Com a madeira valorizada por sua integração no circuito mercantil, havia uma pressão dos proprietários de terra para transformar a colheita da lenha em delito. A alternativa a isso seria sua manutenção como bem para satisfação de necessidades elementares, e um embate, então, ocorre entre duas formas de direito, o de propriedade e o dos costumes, que incluíam direito de passagem, de

\footnotetext{
${ }^{14}$ Ver "Marxism and the vernacular revolutionary traditions", em Shanin (1983, p. 275).
} 
pasto e colheita de lenha. Estava, assim, em jogo, a definição da propriedade.

Marx argumenta que para se apropriar de madeira verde, esta deveria ser arrancada com violência, o que iria contra a integridade da árvore e o direito de propriedade. No entanto, quando se trata de galhos, nada seria tirado da propriedade, além do que já havia caído. O proprietário possui a árvore, mas a árvore não possui mais os galhos. Assim, são duas coisas bem distintas, e, ao considerar duas práticas diferentes como atentado contra a propriedade privada, a lei ficaria atenuada onde deveria ser aplicada. Marx pensa, nesse contexto, com Proudhon e pergunta se qualquer propriedade não seria um roubo, pois, sendo proprietário, excluo qualquer outra pessoa dessa possibilidade.

Em seguida, Marx efetua defesa dos direitos dos pobres, dos direitos de costume e dos não proprietários diante dos proprietários. Alguns objetos deveriam pautar220 -se pelo direito de ocupação da classe, que excluída de qualquer propriedade, "ocupa na sociedade civil a mesma posição que estes objetos na natureza” (Marx, 1984 [1842], p. 104). Marx defende um sentido instintivo do direito dos que nada possuem. Ademais, com Locke, diz que tal propriedade não é legítima, pois não passou por uma ação transformadora, por um trabalho. Aplica-se, nesse caso, o direito de ocupação.

Marx opõe, assim, a propriedade comunal - que seria no princípio generalizada - à privada. Retomando as Formen, o capitalismo tem como pressuposto a separação do trabalhador dos meios de produção. Isto é, a separação do trabalhador de sua terra, o que "significa a dissolução tanto da pequena propriedade livre quanto da propriedade comunal da terra assentada sobre a comuna oriental”. Nesta, os indivíduos são proprietários, como membros da comunidade em que vivem e trabalham. Seu objetivo é a manutenção da família e não a criação de valor e a terra "é o grande laboratório, o arsenal 
que proporciona tanto os meios e objetos do trabalho como a localização, a base da comunidade. [...] Eles se consideram como seus proprietários comunais" (Marx, 2011 [1857-1858], pp. 65-67; grifos do autor).

Nos Manuscritos parisienses, Marx (2004 [1844], p. 75) já compreende "a propriedade fundiária" como "raiz da propriedade privada". Ademais, em "A nacionalização da terra", Marx defende que "a propriedade do solo é a fonte original de toda riqueza e ela se transformou no grande problema cuja solução determinará o futuro da classe operária”, salientando que juristas, filósofos e economistas "disfarçam esse fait initial da conquista sob o argumento do 'direito natural'"15, evidentemente direito natural de alguns.

Tal visão é enriquecida nos chamados Cadernos Kovalevsky. Em setembro de 1879, em meio ao seu período de estudos sobre as sociedade agrárias para a redação do volume 3 do Capital, Marx recebe do historiador russo Kovalevsky seu livro Obshchinnoe Zemlevladenie e "como resultado de sua leitura, Marx redigiu, entre notas, comentários e transcrições, mais de oitenta páginas de um dos seus cadernos”. Marcam Marx certos argumentos convergentes com os seus, principalmente o sobre a propriedade comunal da terra e sua existência "nos momentos iniciais do surgimento da organização social dos homens". Marx (re)pensa a distinção entre posse e propriedade da terra e "dá conta da impossibilidade de aplicar o mesmo conceito de 'propriedade' usado para a Europa, para estudar sociedades onde a terra não pode ser alienada (vendida)" (García Linera, 2008, pp. 23-25). Marx troca sistematicamente "propriedade" por "posse" nesses Cadernos, indicando a comunidade como proprietária e os indivíduos como possuidores da terra.

Ademais, o autor reforça sua visão de uma diversidade dos caminhos do desenvolvimento histórico dos povos, iro-

\footnotetext{
${ }^{15}$ Ver "La nationalisation de la terre" (1872), em Rubel (1963, p. 1476).
} 
nizando os feudalismos encontrados por Kovalevsky. Em muitas partes do mundo, não ocorreu transição entre duas formas de propriedade privada, da feudal para a capitalista, mas sim de uma forma comunal para uma privada. Não se trata de pensar uma sucessão progressiva, mas a existência de "formas sociais particulares que precederam indistintamente o surgimento do regime capitalista em distintas zonas geográficas do planeta", indicando uma "extraordinária diversidade das modalidades organizativas da sociedade humana e, em particular, sobre a existência de uma muito longa etapa da vida comunitária de todos os povos" (García Linera, 2009, p. 237). Caminhos a serem descobertos e enriquecidos.

A propriedade comunal deixa de ser localizada em um só lugar (Índia) ou em alguns (Índia e Europa) para se generalizar, sendo assim o início da trajetória de todos os povos. A propriedade comunal da terra como instituição primeira para Engels. Nos anos 1880, a Índia é considera222 da somente uma das extremidades de um arco de sociedades de propriedade coletiva; "a partir desse momento para Engels a forma típica do comunismo primitivo é a forma social das tribos americanas analisadas por Morgan, e não mais a forma das sociedades asiáticas”. Desse modo, na tradução inglesa de $O$ capital (na publicação de 1887), Engels tira o termo "oriental" da expressão "propriedade comum oriental" (Thorner, 1969, p. 363). Nesse contexto, a discussão sobre a comuna russa e sobre Morgan liga-se diretamente ao pensar em Marx num contexto latino-americano.

Se existe uma ruptura entre as sociedades sem classes e as sociedades de classes, como pensá-la, assim como seus elos também existentes? Ao reconhecer essa diferença-chave entre sociedades sem classes e sociedades de classe, o que pensar dos estágios de desenvolvimento? Como vimos, em A ideologia alemã, Marx e Engels rejeitam qualquer "teoria histórico-filosófica” e situam sua argumentação sobre "evolução histórica" com algumas abstrações. E, em seus 
escritos a partir da década de 1860, Marx vai ignorar ou deixar de lado qualquer sistema classificatório geral; em O capital não há lista dos modos de produção, somente é citada a sequência europeia ocidental - isto é, escravismo, feudalismo e capitalismo. Ao não usar os estágios da mesma forma que o havia feito anteriormente, Marx escapa de apreensões esquemáticas, pois “uma vez 'capturados' no movimento da história universal, os espaços não europeus teriam como destino o de repetir as etapas do percurso tomado pelo Europa”.

A compreensão de Marx aproxima-se de uma perspectiva de multiplicidade de tempos e de relações sociais que são, também, contemporâneas. Há certa sucessão no tempo, mas também curtos-circuitos. Isso torna possível pensar numa articulação outra que não uma linha linear e progressiva do tempo histórico. Permite, assim, compreender a questão da diferença entre sociedades de e sem classes por uma via diferente. Nesse sentido, o filósofo italiano Sandro Mezzadra critica o discurso hegeliano de expansão e mundialização do espírito e da racionalidade a partir da Europa, argumentando que este cria uma divisão temporal e espacial e uma dicotomia entre história e não história. Dessa forma, "a fronteira era precisamente construída como absoluta para ser ultrapassada. A expansão colonial encontrava-se assim inscrita nos pressupostos epistêmicos da modernidade europeia" (Mezzadra, 2006, pp. 76-77).

A narração linear, do centro em direção à periferia, é substituída por uma inter-relação permanente. Por via de uma mútua influência, as colônias constituem laboratórios da modernidade tanto quanto as metrópoles. Trata-se de um sistema mundial híbrido e, assim, não faz sentido opor "tradição" e "modernidade", pois as "civilizações pré-coloniais são em muitos casos muito avançadas, ricas, complexas e sofisticadas; e as contribuições dos colonizados à assim chamada civilização moderna são substancial e em grande 
medida não reconhecidas" (Hardt e Negri, 2009, p. 68). Além disso, com a expansão - quase ao limite do planeta do modo de produção capitalista, todos estamos inseridos numa mesma contemporaneidade.

Tais contemporaneidade e simetria dos tempos estão presentes nos elos entre comunismo primitivo e comunismo por vir. Para Marx e Engels, o sistema capitalista "criou pela primeira vez a história mundial”. Esta nem sempre existiu. Trata-se de um resultado e o comunismo é entendido nesse contexto, pois "pressupõe o desenvolvimento universal da força produtiva e o intercâmbio mundial associado a esse desenvolvimento" (Marx e Engels, 2007 [1845-1846], p. 60).

Marx conjuga, como o apontou Claude Lefort, uma história evolutiva - via o desenvolvimento das forças produtivas - e uma repetitiva - ligada à comunidade mediadora entre produtores e fatores de produção. Assim, "o pré-capitalismo é apreendido desde o capitalismo, como seu outro" (Lefort, 224 1978, p. 338; grifo do autor) e, numa revolução copernicana, o que deve ser explicado é a separação dos trabalhadores dos seus meios de produção. Esta - e não o contrário - é a exceção. Como vimos, a conclusão de Morgan é retomada por Marx e Engels, assim como as formas sociais igualitárias e sem classes constituem inspiração para futuras organizações. O mir deveria, dessa forma, romper seu isolamento e utilizar a modernidade e suas tecnologias.

A compreensão do "comunismo primitivo" relaciona-se com uma dimensão metodológica das Formen. Trata-se do método regressivo e não de uma perspectiva que busca demonstrar o progresso. Marx parte da fundamental separação dos trabalhadores dos seus meios de produção - a terra sobretudo - "para então investigar as formas de unidade que foram sendo negadas, dissolvidas, suprimidas, ao longo da evolução social" (Quartim de Moraes, 1995, p. 116). Mais do que o "comunismo primitivo" existiriam, assim, comunismos primitivos ou uma multiplicidade de 
formações sociais sem classes que a antropologia investiga. Marx toma um caminho não de buscar um esquema totalidade de progresso, mas algo no sentido de opor à apropriação privada diversas formas comunais. Não pensa numa sucessão linear de modos de produção e os processos inglês e europeu ocidental não são antecipação dos demais.

Retomando a questão das enclosures, condição do surgimento do capitalismo, a destruição que essas causam não se situa unicamente no meio de vida e subsistência dos camponeses pobres, mas principalmente numa "inteligência coletiva concreta, ligada a esse comum do qual todos dependiam" (Stengers, 2009, p. 108), num patrimônio comum de criações coletivas. A filósofa belga Isabelle Stengers propõe, assim, um deslocamento da famosa frase do Manifesto já citada sobre a história das lutas de classes, pensando que descendemos ou das bruxas - isto é das criações coletivas pré-capitalistas - ou de seus caçadores; do pensamento dominante e unificador (capitalista) ou dos múltiplos comuns. O que uniria essas relações sociais pré-capitalistas tão distintas? Ao menos o fato de a expansão capitalista buscar destruí-las todas. Em termos marxistas, trata-se da oposição dessas diferentes formas sociais e econômicas à apropriação privada.

Tal perspectiva não seria, pensa-se, estranha a Marx, pois este afirma que "a história do declínio das comunidades primitivas ainda deve ser escrita (seria incorreto colocar todas no mesmo plano, até agora temos só esboços)" (Marx, 1983, p. 107). O autor pensa, além disso, nos potenciais revolucionários dessas formas sociais outras. Ou seja, o sentido de "comunismo primitivo" refere-se mais a um antagonismo à apropriação privada que uma mesma forma de todos os povos numa etapa inicial. Para apreender tais relações sociais, necessita-se, como Marx colocou no caso russo, descer da teoria pura rumo à realidade. Nesse contexto, situa-se a força da antropologia, já que as diversas formas de "comunismo primitivo" - e inclusive a pertinência 
ou não deste conceito - não são pensáveis sem sua contribuição específica.

Toda época vive a possibilidade de libertar os seus e os outros. Walter Benjamin (1991 [1940], p. 228) pensa, nesse âmbito, o papel do proletariado, como a "última classe escravizada, a classe vingadora que, em nome de gerações de derrotados, leva a termo a obra de libertação. Essa concepção que, por um momento, deverá reviver nas revoltas de Spartacus". Não por acaso, no "Questionário Proust" que Benjamin certamente não conhecia -, o herói preferido de Marx é... Spartacus! ${ }^{16}$. Pode-se dizer que a partir das lutas, um diálogo entre Marx e os outros se coloca, indicando um elo profundo entre resistências em distintos momentos históricos e locais geográficos. Diálogo em construção.

\section{Jean Tible}

é professor de Relações Internacionais do Centro Universi226 tário Fundação Santo André e diretor de projetos da Fundação Friedrich Ebert (FES).

\section{Bibliografia}

ALMEIDA, M. W. B. 2003. "Marxismo e antropologia". In: TOLEDO, C.

N. et. al. (orgs.). Marxismo e ciências humanas. Campinas: Editora Xamã/ CEMarx/Fapesp..

ARICÓ, J . 1982. Marx e a América Latina. Rio de Janeiro: Paz e Terra.

AVINERI, S. (org.). 1969. Karl Marx on colonialism and modernization: his

dispatches and other writings on China, India, Mexico, the Middle East and North Africa. New York: Anchor Books.

BAKUNIN, M. 2003 [1873]. Estatismo e anarquia. São Paulo: Ícone.

BENJAMIN, W. 1991 [1940]. "Sur le concept d'histoire". In: Écrits français.

Paris: Gallimard.

BERT, J.-F. (org.). 2010. Trois lettres à propos du mode de production asiatique (juin 1853). Estrasburgo: La Phocide.

DUSSEL, E. 1990. El último Marx (1863-1882) y la liberación latinoamericana.

México: Siglo Veintiuno.

${ }^{16}$ Ver "Confessions (Proust Questionnaire)" (1868), em Shanin (1983, p. 140). 
GARCÍA LINERA, A. 2008. "Marxismo y mundo agrario". In: La potencia plebeya. Acción colectiva e identidades indígenas, obreras y populares en Bolivia. Buenos Aires: Prometeo libros/Clacso. . 2009. Forma valor y forma comunidad. La Paz: Clacso/Muela del Diablo Editores Comunas.

HARDT, M.; NEGRI, A. 2009. Commonwealth. Cambridge: Harvard University Press.

HOBSBAWM, E. 1991 [1964]. "Introdução". In: MARX, Karl. Formações econômicas pré-capitalistas. São Paulo: Paz e Terra.

JANI, P. 2002. "Karl Marx, eurocentrism, and the 1857 Revolt in British India”. In: BARTOLOVICH, C.; LAZARUS, N. (orgs.). Marxism, modernity, and postcolonial studies. Cambridge: Cambridge University Press.

KRADER, L. 1974. "Introduction”. In: KRADER, L. (org.). The ethnological notebooks of Karl Marx: studies of Morgan, Phear, Maine, Lubbock. Assen, The Netherlands: Van Gorcum \& Comp. B. V.

LEFORT, C. 1978. "Marx: d'une vision de l'histoire à l'autre". In: Les formes de l'histoire. Paris: Gallimard.

MARX, K. 1946. "De la Asociación Internacional de Trabajadores a Abraham Lincoln” (1864). In: MARX e ENGELS. La Guerra Civil en los Estados Unidos. Buenos Aires: Lautaro.

. 1963. "Lettre au conseil éditorial de Otechestvennye Zapiski, réponse à Mikhailovski” [novembro de 1877]. In: RUBEL, M. (org.). Karl Marx oeuvres I. Paris: La Pléiade.

. 1972. "La Guerra Civil en los Estados Unidos" [25 de outubro de 1861]. In: MARX, K.; ENGELS, F. Materiales para la historia de América Latina. Córdoba: Cuadernos de Pasado y Presente. . 1974. "Réponse à Vera Zasulich" [8 de março de 1881]. In: RUBEL,

M. Marx critique du marxisme. Paris: Payot. 1983. "The 'first' draft". In: SHANIN, T. (org.). Late Marx and the Russian road: Marx and "the peripheries of capitalism". New York: Monthly Review Press. 1984 [1842]. "Débats sur la loi relative au vol de bois". In:

LASCOUMES, P.; ZANDER, H. Marx: du "vol de bois" à la critique du droit. Paris: PUF. (Édition critique de "Débats sur la loi relative au vol de bois" et "Justification du correspondant de la Moselle"). . 1987 [1865]. Salário, preço e lucro. São Paulo: Editora Moraes. . 2004 [1844]. Manuscritos econômico-filosóficos. São Paulo: Boitempo. 2006 [1867]. Le capital (Livre Premier). Paris: PUF. 2011 [1857-1858]. Grundrisse: manuscritos econômicos de 1857-1858. Esboços da crítica da economia política. São Paulo: Boitempo. 
MARX, K.; ENGELS, F. 1996. "Prefácio à edição russa de 1882". In:

NOGUEIRA, M. A. (org.). O manifesto do partido comunista. Petrópolis: Vozes. 2001 [1848]. Manifesto do Partido Comunista. São Paulo: Fundação Perseu Abramo. 2007 [1845-1846]. A ideologia alemã. São Paulo: Boitempo.

MEZZADRA, S. 2006. “Temps historique et sémantique politique dans la critique post-coloniale”. Multitudes, v. 3, n. 26, pp. 76-77.

2008. La condizione postcoloniale: storia e politica nel presente globale. Verona: Ombre Corte.

MORGAN, L. H. 1964 [1877]. Ancient society. Cambridge: The Belknap Press of Harvard University Press.

QUARTIM DE MORAES, J. 1995. “A 'forma asiática' e o comunismo agrário primitivo”. Crítica marxista, São Paulo, Unicamp, v. II, pp. 107-28.

RAULIN, A. 2010. "Sur la vie et le temps de Lewis Henry Morgan”. L'homme, n. 195-196, pp. 225-46.

ROSEMONT, F. 1989. "Karl Marx and the Iroquois". In: Arsenal. Chicago: Black Swan Press.

RUBEL, M. 1974. Marx critique du marxisme. Paris: Payot. . 1963. (org.). Karl Marx oeuvres I. Paris: La Pléiade.

228 SAID, E. 2007 [1978]. Orientalismo: o Oriente como invenção do Ocidente. São Paulo: Companhia das Letras.

SHANIN, T. (org.). 1983. Late Marx and the Russian road: Marx and "the peripheries of capitalism". New York: Monthly Review Press.

STENGERS, I. 2009. Au temps des catastrophes: résister à la barbarie qui vient. Paris: La Découverte.

THORNER, D. 1969. "Marx et l'Inde: le mode de production asiatique". Annales. Économies, Sociétés, Civilisations, v. 24, n. 2.

WADA, H. 1983. "Marx and revolutionary Russia”. In: SHANIN, T. (org.). Late Marx and the Russian road: Marx and "the peripheries of capitalism”. New York: Monthly Review Press.

WHITE, L. A. 1964 [1877]. "Introduction”. In: MORGAN, L. H. Ancient society. Cambridge: The Belknap Press of Harvard University Press.

ZASULICH, V. 1974. "Lettre à Marx" [16 de fevereiro de 1881]. In: RUBEL, M. Marx critique du marxisme. Paris: Payot. 


\section{MARX E OS OUTROS}

\section{JEAN TIBLE}

Resumo: Como Marx e Engels apreendem as outras formas de organização política e social? Eram os autores eurocêntricos? Para abordar tais críticas e eventuais insuficiências, faz-se necessário um estudo dos textos de Marx e Engels, cujos temas vão além da Europa Ocidental. Escritos bastante numerosos e diversos, tendo sido questões pensadas ao longo de suas vidas, desde a investigação sobre as formas sociais pré-capitalistas e os fatores da evolução social já em A ideologia alemã, em 1845-1846, aos Cadernos etnológicos de Marx, de 1880-1882, passando pelos inúmeros artigos, cartas e comentários, nos quais Marx e Engels analisam situações concretas acerca da Índia, Irlanda, China, Estados Unidos, América Latina, entre outras.

Palavras-chave: Karl Marx; Eurocentrismo; América Latina; Alteridade; Colonialismo.

\section{MARX AND THE OTHERS}

Abstract: How did Marx and Engels apprehend others forms of social and political organization? Were the authors Eurocentric? To work those critics and eventual insufficiencies, a study of the Marx and Engels' texts about non-European themes is made necessary. Varied and numerous writings, those questions being thought during all life, from the investigation about the pre-capitalists social forms and the factors of the social evolution in The German ideology in 18451846 to the Ethnological notebooks of Marx in 1880-1882, passing by the in-countless letters, commentaries and articles on which Marx and Engels analyze concrete situations about India, Ireland, China, United States, among others.

Keywords: Karl Marx; Eurocentrism; Latin America; Alterity; Colonialism. 